\title{
Potential Protective Effects of Ganoderma lucidum Powder against Carbon Tetrachloride Induced Liver Disorders in rats: Biological, Biochemical and Immunological Studies
}

\author{
Sara A. Sayed Ahmed"; Nahed S. Abd Elalal' ${ }^{1}$ and Yousif A. Elhassaneen ${ }^{3 *}$ \\ ${ }^{I}$ Department of Home Economics, Faculty of Specific Education, Port Said University, Port Said; \\ ${ }^{2}$ Department of Home Economics, Faculty of Specific Education, Zagazig University, Zagazig; and \\ ${ }^{3}$ Department of Nutrition and Food Science, Faculty of Home Economics, Minoufiya University, \\ Shebin El-Kom, Egypt \\ *Corresponding Author: yousif12@hotmail.com
}

\section{ABSTRACT:}

iver is the main organ in the body for intense metabolism and excretion. A large number of chemicals and medicines/drugs used routinely in daily lives can cause disorders and possibly liver disease. The aim of exploring some aspects related to the potential hepatoprotective activity of Ganoderma lucidum versus carbon tetrachloride $\left(\mathrm{CCl}_{4}\right)$ intoxication in rat liver. When compared with the normal group rats, the $\mathrm{CCl}_{4}$ treated rats showed significant $(p \leq 0.05)$ decreased in different biological parameters. Also, biochemical parameters such liver enzymes activities were significant $(p \leq 0.05)$ elevation when compared with the normal group rats. For immunological parameters, Alb was significant $(p \leq 0.05)$ decreased by the rate of -29.44 and TNF- $\alpha$ increased by $93.28 \%$. This also coincided with an imbalance in the oxidants/antioxidants status in the blood, which was represented by a decrease in the level of antioxidants and a high level of oxidants. All of those parameters were indicating the liver injury by $\mathrm{CCl}_{4}$. Whereas animal treated/fed with Ganoderma lucidum powder (GLP) showed significant ( $\leq \leq 0.05)$ improvements in all previous status biomarkers indicating the protection against hepatic cell damage. A positive dose - response was recorded between the concentrations of GLP applied and the level of improvement noticed in all measured markers. In conclusion, GLP was effective in protecting against $\mathrm{CCl}_{4}$-induced liver disorders. Present study recommended like of that algae powder by a concentrations up to 5\% (w/w), amount to be included in daily diets, drinks and food supplementation after trial study on volunteer human.

Keywords: Ganoderma lucidum, powder, biomarker of biological and immunity.

Abbreviations: Alb, albumin; GSH, reduced glutathione; GSSG, oxidized glutathione; GSH-Rd, glutathione reductase; GSH-Px, glutathione peroxidase; IL-1, Interleukin 1; IL-6, Interleukin 6; IL8, Interleukin 8; $M D A$, malondialdehyde; Nitrite, $\mathrm{NO}_{2}$; $\mathrm{ROS}$, reactive oxygen species; OS, oxidative stress, TBA, thiobarbituric acid; TNF- $\alpha$, tumor necrosis factor-alpha.

Bulletin of the National Nutrition Institute of the Arab Republic of Egypt. December 2020 (56) 99 


\section{INTRODUCTION}

Liver is the vital organ, which plays a critical role in all vertebrates. It performs a number of life functions including processes many products released into the blood stream (e.g. glucose, plasma proteins and urea), synthesis some of the clotting factors needed to stop bleeding, produces and secretes bile to aid nutrient absorption, and stored several products (e.g. glycogen, fat, vitamins and minerals) (Crawford, 1999; Elhassaneen, 1996 and Kebamo et al., 2015). The liver also plays a very important part in the biotransformation/ removal of xenobiotics from the body, among which alcohol, food toxins, and medicinal agents are especially noteworthy (Grażyna et al., 2020; Yu et al., 2020). Because of these vital functions, the liver is subjected to a variety of insults and is one of the most vulnerable organs in the body. Many studies reported that these liver functions are associated with the disturbance of hepatocyte biochemistry and inducing oxidative stress through generation of reactive oxygen species (ROS) (Valko et al., 2004; Rahman et al., 2012). Many chemicals, which are used on a routine basis, produce cellular and metabolic liver damage (Meyer and Kulkarni, 2001). The most commonly used chemical is carbon tetrachloride $\left(\mathrm{CCl}_{4}\right)$. It is anticipated to be a human carcinogen based on sufficient evidence of carcinogenicity from studies in experimental animals. World Health Organization (WHO, 1999) reports $\mathrm{CCl}_{4}$ can induce hepatomas and hepatocellular carcinomas in rats and mice. In addition, it causes hepatotoxic effects by producing centrilobular necrosis and steatosis. Vanitha et al., (2007) reported that six hours after single dose, $(2 \mathrm{ml} / \mathrm{kg})$ of treatment of $\mathrm{CCl}_{4}$ caused liver toxicity through disturbance in serum biomarker enzymes. DeGroot and Noll, (1986) involving lipid peroxidation of 
membrane-bound fatty acids that results in destructing the cell membrane and intracellular organelles of the hepatocyte, explained the mechanism of hepatic injury by CCl4. All of those previous studies with the others indicated that one of the best models of injury produced in liver is by $\mathrm{CCI}_{4}$.

Modern pharmacological therapy is expensive and associated with numerous side effects, which leads to patient noncompliance. Thus, there is a need to investigate alternative therapies, particularly those derived from plants, because they have a wide range of biological and medicinal activities, are cost effective, and have few side effects (Elhassaneen et al., 2016 a and b). Ganoderma lucidum, an oriental fungus, has a long history of use in different Asian countries, particularly China and Japan, for promoting health and longevity. It has been recognized as a medicinal mushroom for over 2000 years and widely used in folk medicine which was attributed with therapeutic properties, such as, antiaging effects, strengthening cardiac function, enhancing vital energy, increasing memory, and tonifying effects (WachtelGalor et al., 2011). In addition, G. lucidum acts to relieve cough and asthma, replenish Qi, ease the mind, and it is recommended for dizziness, palpitation, insomnia, and shortness of breath (State Pharmacopoeia of the People's Republic of China, 2000). In recent decades, its powerful effects have been documented as anticancer, antitumor, immune modulatory, antioxidant, antibacterial, antiviral and antidiabetic (Tomasi et al., 2004, Evans et al., 2009, Ma et al., 2008, Wu and Wang 2009, Zhong and Xiao 2009 and Gao, et al., 2004). Most if not all studies related to the effect of G. lucidum on liver injury have been conducted by using mushroom extracts or one of its isolated bioactive molecules such as polysaccharides, terpenoids, steroids, nucleotides, phenols and glycolproteins. However, the hepato- 
protective effects of G.Lucidum powder and all of its constituents against liver damage in animal models are unknown. Therefore, this study was conducted with the aim of exploring some aspects related to the potential hepatoprotective activity of Ganoderma lucidum against carbon tetrachloride intoxication in rat liver.

\section{MATERIALS AND METHODS}

\section{Ethical approval}

Biological experiments for this study were ethically approved by the Scientific Research Ethics Committee (Animal Care and Use), Faculty of Home Economics, Menoufia University, Shebin El-Kom, Egypt (Approval no. 02- SREC08-2018).

\section{Materials and chemicals}

Dried fruits of the fungus Ganoderma lucidum (Reishi) were obtained from ElMisryia Company for Trading Herbs and Medical Plants (Haraz), Bab ElKhalk, Cairo, Egypt. Taxonomic confirmation of G. lucidum was carried out by Agricultural Plant Department, Faculty of Agriculture, Menoufia University, Shebin El-Kom, Egypt. Carbon tetrachloride $\left(\mathrm{CCl}_{4}\right)$, as $10 \%$ liquid solution, was obtained from ElGhohorya Company for Trading Drugs, Chemicals and Medical Suppliers, Cairo Egypt. Kit's assays for Alanine aminotransferase (ALT), aspartate aminotransferase

(AST), alkaline phosphatase (ALP) and malondialdehyde (MDA) were purchased from Bio-Diagnostic, Dokki, Giza, Egypt. Albumin (Alb) was determined using kits purchased from El-Nasr Pharmaceutical Chemicals Company, Cairo, Egypt. TNF- $\alpha$ was assayed by kit was provided by Nawah Scientific, Almokattam, Cairo, Egypt. The kits provided by MyBioSource, Inc., San Diego, CA, USA, assayed GSH and GSSG. Casein was obtained from Morgan Chemical Co., Cairo, Egypt. All other chemicals and solvents used were of analytical grade were purchased from ElGhohorya Company for 
Trading Drugs, Chemicals and Medical Suppliers, Cairo Egypt.

Preparation of powder from $G$. lucidum

Dried fruits of $G$. lucidum were ground into a fine powder in high mixer speed (Moulinex Egypt, Al-Araby Co., Egypt). The material that passed through an 80-mesh sieve was retained for use.

\section{Biological experiments}

\section{Animals:}

Animals used in this study, adult male albino SpragueDawley rats $(140 \pm 9.56 \mathrm{~g}$ per each) were obtained from Research Institute of Ophthalmology, Medical Analysis Department, Giza, Egypt.

\section{Basal Diet (BD):}

The BD prepared according to the following formula as mentioned by Reeves et al., (1993).

\section{Induction of liver intoxication in Rats:}

Thirty-six male albino rats were administrated by intraperitoneal (IP) injection of carbon tetrachloride $\left(\mathrm{CCl}_{4}\right)$ in paraffin oil, $50 \% \mathrm{~V} / \mathrm{V}(2 \mathrm{ml} / \mathrm{kg}$ bwt), twice a week for two weeks to induce chronic damage of the liver according to the method described by Jayasekhar et al., (1997). Liver intoxication was confirmed by taking a random sample of experimental animals (4 rats) and measuring liver function tests.

\section{Experimental design}

All biological experiments performed a complied with the rulings of the Institute of Laboratory Animal Resources, Commission on life Sciences, National Research Council (NRC, 1996). Rats $(n=42$ rats) were housed individually in wire cages in a room maintained at $26 \pm 3{ }^{\circ} \mathrm{C}$, relative humidity $(54 \pm 4 \%)$, a 12-hr lighting cycle and kept under normal healthy conditions. All rats were fed on $\mathrm{BD}$ for one-week before starting the experiment for acclimatization. After one-week period, the rats were divided into main groups. First group (6 rats), as a 
normal control group, fed on $\mathrm{BD}$ and injected with paraffin oil $(2 \mathrm{ml} / \mathrm{kg}$ body weight) which was used as a vehicle for the treatment of animals in $\mathrm{CCl}_{4}$ group. Second main group (36 rats) was injected with $\mathrm{CCl}_{4}$ to induce liver impaired rats then classified into sex equal sub groups as follow: group (2), as a positive control group, fed on BD and groups (3-6) fed on BD containing 1, 2, 3, 4 and 5\% (w/w) GLP, respectively. Each of the above groups was kept in a single cage for 28 days. Rats were weighted at the beginning of experimental then weekly and at the end of the experimental period.

\section{Biological evaluation}

During the experimental period (28 days), the diet consumed was recorded twice a weekly and body weight was recorded every week. The body weight gain (BWG, \%), feed intake (FI) and feed efficiency ratio (FER) were determined according to Chapman et al., (1959) using the following equations:
BWG\% $=($ Final weight - Initial weight)/ Initial weight $\times 100$ FER = gain in body weight ( $\mathrm{g} / 28$ day)/ feed intake $(\mathrm{g} / 28$ day)

\section{Blood sampling}

At the end of experiment period, 4 weeks, blood samples were collected after 12 hours fasting using the abdominal aorta and rats were scarified under anesthetized. Blood samples were received into clean dry centrifuge tubes and left to clot at room temperature. Then centrifuged for 10 minutes at $3000 \mathrm{rpm}$ to separate the serum according to Drury and Wallington, (1980). Serum was carefully aspirate, transferred into clean Eppendorf tubes and stored frozen at $-20^{\circ} \mathrm{C}$ until analysis.

\section{Liver functions parameters}

Serum alanine aminotransferase (ALT) and serum aspartate aminotransferase (AST) activities were measured in serum using the modified kinetic method of Tietz et al., (1976) by using kit supplied by Biocon Company. Alkaline Phosphatase (ALP) 
activity was determined using modified kinetic method of Vassault et al., (1999).

\section{Immunological assays}

Albumin was determined in serum according to the method of David et al., (1954) using kits purchased from El-Nasr Pharmaceutical Chemicals Company, Cairo, Egypt. TNF- $\alpha$ was determined such as mentioned by Tavakkol et l., (2005) by a sandwich enzymelinked immune-sorbent assay (ELISA), utilizing two monoclonal antibodies directed against separate antigenic determinants on rat TNF- $\alpha$. Adlitteram Diagnostic Laboratories Inc. (San Diego, CA, US) provided the kits for the assay.

\section{Biomarker antioxidants}

Glutathione fractions (GSH and GSSG) were measured colorimetric- ally in serum samples such as described by Ellman, (1959).

\section{Biomarker oxidants}

Serum nitrite $\left(\mathrm{NO}_{2}\right)$ was determined flourometric such as described by Misko et al., (1993). Serum malonaldialdehyde (MDA) content was measured by the thiobarbituric acid (TBA) method according to the methods of Buege and Aust, (1978).

\section{Statistical Analysis}

All data were statistically analyzed using a computerized cost at program by one-way ANOVA. Results were given as means \pm Standard Deviation (SD). Differences between treatments at $\mathrm{P} \leq 0.05$ were considered significant (Snedecor and Cochran, 1967).

\section{RESULTS AND DISCUSSION}

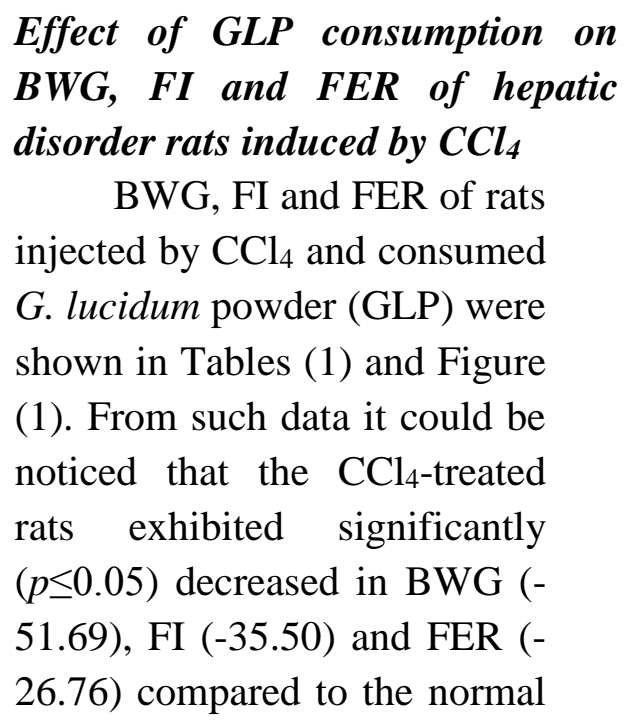
$B W G, F I$ and FER of hepatic BWG, FI and FER of rats 
group. However, supplementation of the rat diets with GLP $(1.0$ to $5.0 \mathrm{~g} / 100 \mathrm{~g})$ for 28 days significantly $(p \leq 0.05)$ increased the levels BWG, FI and FER with the positive control group. The rate of increasing in all those parameters exhibited a dose dependent increase with GLP consumption. Such data are in agreement with that observed by Salman, (2016) and Elhssaneen et al., 2019; and Essa, 2021) in different genus of algae. In addition, Hamzawy et al., (2013) and Abd El-Rahman (2021) reported that hepatic rats reveal significant reduction of the body weight and feed intake. Furthermore, Morresion and Hark, (1999) showed that liver disease can lead to malnutrition and the major causes of malnutrition in patients with liver disease are poor dietary/feed intake (FI), maldigestion, malabsorption and abnormalities in the metabolism and storage of macro and micro nutrients. With the same context, Dickerson and Lee, (1988) reported that many patients with acute or chronic liver disease are ill and commonly lose weight. Additionally, Elbanna, (2014), Mansour, 2017, Tahoon, 2019 and Elhassaneen et al., (2021) found that injected rats by $\mathrm{CCl}_{4}$ caused decrease in both FER and BWG and improved by consumption plant parts contains bioactive compounds such as found in GLP.

Effect of G. lucidum consumption on liver functions of hepatotoxic rats induced by $\mathrm{CCl}_{4}$

Liver functions of rats injected $\mathrm{CCl}_{4}$ and consumed $G$. lucidum powder (GLP) were shown in Table (2) and Figure (2). From such data it could be noticed that the $\mathrm{CCl} 4$-treated rats exhibited significantly $(p \leq 0.05)$ increased levels of AST (74.29\%), ALT (123.55\%) and ALP (176.56\%) compared to the negative control group. However, supplementation of the rat diets with GLP (1.0 to $5.0 \mathrm{~g} / 100 \mathrm{~g})$ for 28 days significantly $(p \leq 0.05) \quad$ decreased the levels of AST, ALT and ALP. The rate of decreasing 
was raised with the increasing of the GLP consumption rate.

$$
\mathrm{CCl}_{4} \text {-induced }
$$

liver damage is commonly used to experimentally study the hepatoprotective effects of drugs (Manibusan et al., 2007; Susilo et al., 2019). Such liver damage came through metabolizes $\mathrm{CCl}_{4}$ to trichloromethyl (CCl3-) radicals by the liver cytochrome P450 which reactively bind to $\mathrm{O}_{2}$ to form trichloromethyl peroxyl (CCl3OO-) radicals. These radicals subsequently cause lipid peroxidation of membranebound fatty acids. Furthermore, the structure and function of the cell membrane and intracellular organelles of the hepatocyte become disrupted. In the present study, CCl4 administration induced severe damage to liver cells, demonstrated by increased serum AST, ALT and ALP levels. Serial enzyme measurements, AST, ALT and ALP are often considered sensitive markers for determining the course of liver damage due to their presence of the cytoplasm facilitates blood flow after liver cell damage (Pagana and pagana, 1997 and
Sayed Ahmed, 2016). Our data also indicated that GLP significantly $(p \leq 0.05)$ reduced AST, ALT and ALP levels which demonstrating that it can prevent cell damage. Such preventive effects could be attributed to GLP content of some important bioactive compounds. In similar studies, G. lucidum extracts mainly polysaccharides or triterpenoids exhibit protective activities against liver injury induced by toxic chemicals including $\mathrm{CCl}_{4}$ (Wachtel-Galor et al., 2011; and Susilo et al., 2019).

Effect of G. lucidum consumption on immunological markers of hepatotoxic rats induced by $\mathrm{CCl}_{4}$

Immunological parameters of rats injected $\mathrm{CCl}_{4}$ and consumed G. lucidum powder (GLP) were shown in Tables (3) and Figure (3). The CCl4-treated rats exhibited significantly $(\mathrm{p} \leq 0.05)$ decreased serum Alb levels (-29.44\%) and significantly $(\mathrm{p} \leq 0.05)$ increased TNF- $\alpha$ levels (93.28\%) compared to the normal control group. The consumption of $G$. 
lucidum extract attenuated these CCl4-induced alterations in Alb and TNF- $\alpha$ level. The rate of attenuation was raised with the increasing of the GLP consumption level. In similar studies, $\mathrm{CCl}_{4}$-induced significant decrease in the serum albumin content as the consequence of liver injury (Wang, et al., 2007, Abd El-Rahman, 2013 and Abd El-Fatah, 2013). In addition, Koneri, et al., (2008), reported that hypoalbuminaemia is most frequent in the presence of advanced chronic liver diseases. Hence, decline in serum albumin can be deemed as a useful index of the severity of cellular dysfunction in chronic liver diseases. In this study, GLP significantly $(p \leq 0.05)$ increased serum Alb levels which demonstrating that it can prevent or repair the hepatocyte damage. Such role of GLP in manipulation the hypoalbuminemia could be of a high degree of importance because human albumin serum is the main protein of blood plasma and makes up around $50 \%$. Transport protein bind to various ligands and carry them around such as water, fatty acids, hormones, bilirubin, thyroxine (T4), pharmaceuticals and cations (including $\mathrm{Na}^{+}, \mathrm{K}^{+}$and $\mathrm{Ca}^{2+}$ ). Thus, the main function of albumin is to regulate the oncotic pressure of blood (Farrugia, 2010).

On the other side, in this study, GLP significantly $(p \leq 0.05)$ decreased serum TNF$\alpha$ levels which demonstrating that it can prevent tissue damage. Such role of GLP in suppression the TNF- $\alpha$ could be of a high degree of importance because it is a pro-inflammatory cytokine, which plays an important role in initiating the tissue inflammatory reaction (Kim et al., 2003). TNF- $\alpha$ damages endothelial cell, promotes leukocyte adhesion of vascular endothelial cells, increases vascular permeability, and stimulates Interleukin 1 (IL1) production by vascular endothelial cells, endothelin, and other inflammatory mediators, leading to tissue inflammation (Ferrero-Miliani, 2007). Also, TNF- $\alpha$ stimulates neutrophil degranulation "outbursts," which produces oxygen free radicals, proteases and lipids, leading to 
tissue damage (Gao, 1999). Furthermore, TNF- $\alpha$ is releasing IL-1, Interleukin 6 (IL-6) and Interleukin 8 (IL-8), and in inflammatory reactions, causing a "cascade effect" and aggravating tissue damage (Bentrem and Joehl, 2003). In similar studies, treatment patients' groups given extracts from the medicinal mushrooms including G. lucidum were found to demonstrate decreased expression of tumor markers, increased natural killer (NK) cells activities, and higher survival rate, compared to control Groups (Kodama et al., 2003; Gao et al., 2004 and Venturella et al., 2021).

Effect of G. lucidum consumption on glutathione fractions of hepatotoxic rats induced by $\mathrm{CCl}_{4}$

Data presented in Table

(4) and Figure (4) showed effect of feeding GLP on serum glutathione fractions content of rats treated with $\mathrm{CCl}_{4}$. It was observed that the mean value of GSH and GSSG for control normal group were 8.61 and $0.671 \mu \mathrm{mol} / \mathrm{L}$. The CCl4-treated rats exhibited significantly $(\mathrm{p} \leq 0.05)$ decreased serum GSH $(-$ $31.36 \%)$ and GSSG (-14.75\%) compared to the normal control group. Supplementation of the rat diets with GLP (1.0 to $5.0 \mathrm{~g} / 100 \mathrm{~g}$ ) attenuated these $\mathrm{CCl} 4$ - induced alterations in GSH and GSSG levels. In addition, a GLP dose dependent increase in all glutathione fractions studied was seen.

GSH is a tripeptide-thiol ( $\gamma$-glutamyl cysteinyl-glycine) that has received great interest in many aspects related to its biosynthesis, regulation and various functions within cells (Voet and Voet 1990). Its role in detoxifications process represent the main function through as a key conjugate of xenobiotics electrophilic metabolites and as an important antioxidant

1996). The antioxidant functions of GSH include serving as a nonenzymatic scavenger of oxyradicals and its role in the activities of the antioxidant enzymes system (glutathione peroxidase, GSH$\mathrm{Px}$ and glutathione reductase, (GSH-Rd) (Wu, et al., 2004 
and Almaadawy et al., 2016)

Therefore, determination of this small molecule is very important for present-day nutrition, medicine and pharmacy. Data of the present study with the others (Hasegawa et al., 1995 and Meharam and Sayed- Ahmed, 2019) suggested that $\mathrm{CCl}_{4}$ might block secretion of glutathione fractions from liver to blood because of intracellular structural failure, elevation of the lipid peroxidation and/or the energy depletion suggested by the marked decrease in glycogen content. Various components of GLP, in particular polysaccharides, terpenoids, phenolics, and flavonoids show antioxidant activity (Wu and Wang 2009; Wong et al., 2013). In addition, Wachtel-Galor et al., (2011) reviewed that antioxidants from G. lucidum were found to be absorbed quickly after ingestion inducing elevate in the plasma total antioxidant activity of human subjects. On the other side, a fall in serum glutathione fractions observed generally in the present study accompanied by a concomitant decreased in the ratio of GSH/GSSG. Di Giulio, (1991) reported that the effect of oxygen-generating compounds refers to its effect on the so-called redox state (GSH / GSSG) of cells or tissues. In the healthy cell, the ratios of GSH/GSSG is typically very high i.e.>10. The $\mathrm{CCl}_{4}$-treated rats exhibited significantly $\quad(\mathrm{p} \leq 0.05)$ decreased in serum redox state (GSH/ GSSG) by $-19.48 \%$. The consumption of GLP by $5 \%$ increased that GSH/GSSG ratio to exactly value recorded by the group of normal rats. It is proposed that GLP suppress $\mathrm{CCl}_{4}$-induced oxyradicals fluxes, which may result in a decrease in the GSH/GSSG ratio.

Effect of G. lucidum consumption on oxidative stress of hepatotoxic rats induced by $\mathrm{CCl}_{4}$

Oxidative stress (OS) of rats injected $\mathrm{CCl}_{4}$ and consumed $\boldsymbol{G}$. lucidum powder (GLP) were shown in Tables (5) and Figure (5). From such data it could be noticed that the 
CCl4-treated rats exhibited significantly $(p \leq 0.05)$ increased levels of MDA (118.44\%), and $\mathrm{NO}_{2}(103.77 \%)$ compared to the normal control group. However, supplementation of the rat diets with GLP ( 1.0 to $5.0 \mathrm{~g} / 100 \mathrm{~g})$ for 28 days significantly $(p \leq 0.05)$ decreased the levels of MDA and $\mathrm{NO}_{2}$. GLP- dose dependent decrease in all the oxidative stress studied was seen.

\section{$\mathrm{CCl}_{4}$-induced liver} damage came through metabolizes $\mathrm{CCl}_{4}$ to its radicals (trichloromethyl, $\mathrm{CCl}_{3}$ ) by the liver cytochrome $\mathrm{P} 450$ which reactively bind to $\mathrm{O}_{2}$ to form trichloromethyl peroxyl $\left(\mathrm{CCl}_{3} \mathrm{OO}^{-}\right)$radicals. Such radicals subsequently cause lipid peroxidation of membranebound fatty acids. Double bonds in fatty acids form peroxide products by reacting with free radicals, and lipid radicals can be formed subsequently upon removal of electrons (Cheeseman and Salter, 1993). Because of lipid peroxidation, harmful degradative products, namely malondialdehyde (MDA) can be formed in cell membranes. MDA shows mutagenic effect via reacting with guanine nucleotide in DNA (Cline et al., 2004). Also, cross linking with the membrane components leads to changes in membrane properties including disturbance in membrane fluidity, inactivation of enzymes and receptors in membranes, cell injury and may cause the formation of atherosclerotic plaques (Kris-Etherton et al., 1999 and Nilanjana., 2013). On the other side, nitric oxide synthase catalyzes the conversion of $\mathrm{L}$-arginine to citrulline and highly reactive free radical species, nitric oxide (NO) (Manahan, 1989). NO, can react with $\mathrm{O}_{2}$ and water to form nitrite $\left(\mathrm{NO}_{2}\right)$ and nitrate $\left(\mathrm{NO}_{3}\right)$; with the amino and thiol groups of protein to produce nitrosylated species; with hemoglobin to form ironnitrosyl adducts and nitrate in blood; and with superoxide anion to make nitrate (Manahan, 1989; Misko et al., 1993).

Several studies indicated that the excess production of nitric oxides in the body has been investigated in the pathogenesis and tissue destruction of a 
growing number of nutritional, communicable, immunological and inflammatory diseases including septic shock, arthritis, graft rejection obesity, anemia, cardiovascular disease, and diabetes (Jacob et al., 1992; Elhassaneen et al., 2020; Mehram et al., 2021). High levels of MDA and $\mathrm{NO}_{2}$ were noted in the present study represents an important finding to support this study hypothesis, i.e. The toxicity of $\mathrm{CCl}_{4}$ is linked to oxidative stress and freeradical damage. Therefore, highly significant decreasing rate on the formation of MDA and $\mathrm{NO}_{2}$ in serum as the result of GLP treatment proposed that hepatoprotection might also be mediated by the radicalscavenging properties, and lipid peroxidation and nitric oxide synthase inhibition of $G$. lucidum. In similar studies, Lin et al. (1991) found that hot water extracts of $G$. lucidum had significant radical-scavenging activity against both superoxide and hydroxyl radicals in similar studies. In addition, Jia et al. (2009) found that treatment of rats with $G$. lucidum bioactive compounds, polysaccharides, leads to decrease the levels of lipid peroxidation and increase the levels of enzymatic and nonenzymatic antioxidants. In our opinion, if there were no change in the antioxidant defense system of rats treated with GLP, it would be difficult to observe low levels of MDA and $\mathrm{NO}_{2}$.

\section{CONCLUSION}

Ganoderma lucidum powder (GLP) was effective in protecting against $\mathrm{CCl}_{4}$-induced liver disorders. These results supported previous hypothesis of the present study that contains several classes of phytochemicals with other compounds that are able to prevent or inhibit $\mathrm{CCl}_{4}$ hepatotoxicity. Through one or more of the following mechanisms: 1) Inhibition of excessive enzymatic activity expressed in liver functions, 2) raising the rate of immune markers in the blood, 3) improving the state of the antioxidant defense system in serum, and 4) reducing the 
degree of oxidative stress in serum i.e. formation of oxidants. Therefore, we recommended like of that algae (Ganoderma lucidum) powder by concentrations up to $5 \%$ $(\mathrm{w} / \mathrm{w})$, amount to be included in our daily diets, drinks and food supplementation after trial study on volunteer human.

\section{REFERENCES}

Abd El-Fatah AM (2013):

Active ingredients in sweet violet and their relation with liver diseases in experimental animals: Biochemical, therapeutic and histopathological studies, Ph.D. Thesis in Nutrition and Food Science, Faculty of Home Economics, Menoufiya University, Egypt.

\section{Abd El-Rahman AN (2013):}

Effects of some Egyptian plant herbs on hypercholestermic rats treated with carbon Tetrachloride" Ph.D. Thesis in Nutrition and Food Science, Faculty of
Home Economics, Menoufiya University, Egypt.
Almaadawy A; Arafa R and Elhassaneen Y (2016):

Oxidative Stress and antioxidant defense systems status in obese rats feeding some selected food processing byproducts applied in bread. Journal of Home Economics, 26 (1): 1 -37. 
Formaldehyde-Induced

Liver Damage in

Experimental Male Rat

Model. Biology, 9, 313.

Bentrem DJ and Joehl RJ (2003):

Pancreas: healing response in critical illness. Crit Care Med, 31(8): 582589.

\section{Buege JA and Aust SD (1978):}

Microsomal lipid peroxidation in Packer L., (ed), Methods in enzymology, New York, NY, Academic, 52: 302 310.

Chapman DG; Castilla R and Champbell JA (1959):

Evaluation of protein in food. I.A.Method for the determination of protein efficiency ratio. Can. J. Biochemistry on Liver Disorder Initiation by carbon Tetrachloride. $M$. Sc Thesis, Faculty of Home Physiology, 37: 679-686.

\section{Cheeseman KH and Salter TF} (1993):
An introduction to free radical biochemistry. $\mathrm{Br}$ Med Bull., 49(3):481-93.

\section{Cline S; James NR; Silvia T;} Lawrence $J$ and Philip $C$ (2004):

Malondialdehyde adducts in DNA arrest transcription by $\mathrm{T} 7 \mathrm{RNA}$ polymerase and mammalian RNA polymerase II. PNAS, 101 (19): 7275-7280.

Crawford JM (1999): The Liver and the Biliary Tract. Pathologic Basis of Disease. Eds. R. S. Cotran, V. Kumar, and T. Collins. W. B. Saunders Company: Philadelphia, USA.

David D; Estelle F; William E
and Jeanne M (1954):
The determination of
albumin in human blood
plasma and serum, a
method based on the
interaction of albumin with
an anionic dye-2-(4-
hydroxybenze azo)
benzoic acid. $J \quad$ Clin
Invest., 33(2): 211-221.




\section{De-Groot $\mathrm{H}$ and Noll T (1986):}

The crucial role of low steady state oxygen partial pressure in haloalkanes free radical induced lipid peroxidation. Possible implications in haloalkane liver injury. Biochem. Pharmacol., 35: 15-19.

\section{Di Giulio RT (1991):}

Indices of oxidative stress as biomarkers for environmental contamination. Aquatic toxicology and risk assessment: $14^{\text {th }}$ volume, ASTM STP 1124, M. A. Mayes and M.G. Barron, Eds., American Society for Testing and MaTERIALS, Philadelphia, pp: 15-31.

Dickerson JW and Lee HA (1988):

Nutrition in the Clinical Mangement of Disease. Second Edition. Edward Arnold. NY.

\section{Drury RA and Wallington EA (1980):}
Carlton's
Histological
Technique. Fifth Ed.
Oxford University, USA.

\section{Elbanna SM (2014):}

Phytochemicals in artichoke (Cynara scolymus, L.) and Their Effects on Liver Disorder Initiation by carbon Tetra Chloride. M. Sc Thesis, Faculty of Home Economics, Menoufia University, Shebin Elkom, Egypt.

\section{Elhassaneen YA (1996): \\ Biochemical and technological studies on pollution of fish with pesticides and polycyclic aromatic hydrocarbons. Ph.D. Thesis., Faculty of Agriculture, Mansoura University, Egypt.}

\section{Elhassaneen Y; Youssef $H$ and} Mansour Z (2016-a):

Hepatoprotective activity and antioxidant effects of avocado peels (Persea americana) on rats hepatotoxicity induced by carbon tetrachloride. 
Journal of Home Elhassaneen Y; Badran H;

Economics, 26 (4): 1-12.

Elhassaneen Y; Ragab $S$ and

Saleh A (2016-b):

Effect of Selected Plant

Parts Extracts on Liver

Injuries Induced by $\mathrm{CCl}_{4}$ in

vitro. Pyrex Journal of

Medicinal Plant Research.

2 (2): 8-20.

Elhassaneen Y; Mekawy Sh;

Khder S and Salman M (2019):

Effect of Some Plant

Parts Powder on Obesity

Complications of Obese

Rats. Journal of Home

Economics, 29 (1): 83-

106.

Elhassaneen Y; El-Dashlouty

$\mathrm{M}$; and El-Gamal N (2020):

Effects of brown algae

(Sargassum subrepandum)

consumption on obesity

induced changes in

oxidative stress and bone

indices. Journal of Home

Economics, 30 (4): 687-

708.

Abd EL-Rahman $A$ and

Badawy N (2021):

Potential Effect of Milk

Thistle on Liver

Disorders Induced by

Carbon Tetrachloride.

Journal of Home

Economics, 31 (1): 83-

93.

\section{Ellman GL (1959):}

Tissue sulfhydryl groups.

Archives of Biochemistry

and Biophysics, 82: 70-

77.

Essa ME (2021):

Chemical and nutritional studies on extracts of food processing by-products and their effects on obesity complications in rats. MSC. Thesis in Nutrition and Food Science, Faculty of Home Economics, Minoufiya University, Shebin El-Kom, Egypt.

Evans S; Dizeyi N; Abrahamsson PA and Persson J (2009):

The effect of novel botanical agent TBS-101 
on invasive prostate cancer in animal models. Anticancer Res. 29:391724.

Farrugia A (2010):

"Albumin usage in clinical medicine: tradition or therapeutic?" Transfusion Medicine Reviews. 24 (1): 53-63.

Ferrero-Miliani L; Nielsen OH; Andersen PS and Girardin SE (2007):

Chronic inflammation: importance of NOD2 and NALP3 in interleukin 1beta generation. Clinical and experimental immunology, 147(2), 227235.

Gao Y; Tang W; Gao H; Chan, E; Lan J and Zhou S (2004):

Ganoderma lucidum polysaccharide fractions accelerate healing of acetic acid-induced ulcers in rats. Journal of medicinal food, 7(4), 417-421.
Gao BH (1999):

The effects of TNF on inflammation. Yi Shi Jin Xiu Za Zhi, 22(11): 55-56.

Grażyna K; Piotr T ; Jan P and Marta S (2020):

Molecular Mechanisms of Ethanol Biotransformation: Enzymes of Oxidative and Nonoxidative Metabolic Pathways in Human. Xenobiotica,1-56.

\section{Hamzawy MA; El-Denshary} ES; Mannaa FA and AbdelWahhab M A(2013):

Dietary supplementation of Calendula officinalis counteracts the oxidative stress and liver damage resulted from aflatoxin. ISRN Nutrition, 9(10), 5402-538427.

\section{Hasegawa R; Chujo T; Sai-} KatoK; UmemuraT; Tanimur a A and Kurokawa Y (1995):

Preventive effects of green tea against liver oxidative DNA damage and hepatotoxicity in rats treated with 2- 
nitropropane. Food Chem

Toxicol., 33(11): 961-70.

Jacob TD; Morrell MK; Manzi

S; Ochoa JB; Verdile V;

Udekwu AO; Berceli SA; Simmons RL and Peitzman AB (1992):

Nitric

oxide:

Implications for drug research. pp.28, IBC, South Natick, MA.

Jayasekhar P; Mohan PV and Rahinam K (1997):

Hepatoprotective activity of ethyl acetate extract of Acacia catechu. Indian. $J$. of Pharmacology, 29:426428.

Jia J; Zhang $\quad$ X; Hu YS; Wu Y; Wang QZ; Li N N; Guo QC; Dong XC(2009) :

Evaluation of in vivo antioxidant activities of Ganoderma lucidum polysaccharides in STZdiabetic rats. Food Chem.; 115:32-6.

Kebamo S; Shibiru $T$ and Bekesho G (2015):
The Role of

Biotransformation in Drug Discovery and Development, $J$ Drug MetabToxicol., 5: 1-13.

\section{Kim GY; Roh SI and Park SK} (2003):
Alleviation
of experimental septic shock in mice by acidic polysaccharide isolated from the medicinal mushroom Phellinus linteus. Biol. Pharm. Bull., 26(10): 1418-1423.

Kodama N; Komuta $\mathrm{K}$ and Nanba H (2003):

Effect of maitake (Grifola frondosa) D-fraction on the activation of NK cells in cancer patients. J. Med. Food, 6(4): 371-377.

Koneri R; Balaraman $\mathbf{R}$ and Firdous-Vinoth KM) 2008):

Hepatoprotective effects of Momordica cymbalaria Fenzl. Against carbon tetrachloride induced hepatic injury in rats. Pharmacol. 1: 365- 74. 
Kris-Etherton PM; Pearson TA; Wan Y; Hargrove RL; Moriarty K; Fishell $\mathrm{V}$ and Etherton TD (1999):

High-monounsaturated fatty acid diets lower both plasma cholesterol and triacylglycerol concentrations. The American journal of clinical nutrition, 70(6), $\quad$ 10091015.

\section{Li YQ and Wang SF (2006):}

Anti-hepatitis B activities of ganoderic acid from Ganoderma lucidum. Biotechno Lett; 28(11):837-41.

\section{Lin C; Tome $\mathrm{W}$ and Won $\mathrm{S}$} (1991):

Novel cytotoxic principles of Formosan Ganoderma lucidum. J. Nat. Prod., 54: 998-1002.

\section{Liu KC; Phounsavan SF;} Huang RL; Liao C; Hsu SY and Wang KJ (1998):

Pharmacological and liver functional studies on mycelium of Ganoderma lucidum. Chin Pharm J.; 40:21-9.

\section{Ma C; Guan SH; Yang M; Liu $X$ and Guo DA (2008): \\ Differential protein expression in mouse splenic mononuclear cells treated with polysaccharides from spores of Ganoderma lucidum. Phytomedicine.; 15:268-76.}

Manahan, S.E. (1989):

Toxicological chemistry: A guide to toxic substances in chemistry, PCR press, New york.

Manibusan MK; Odin M and Eastmond DA (2007):

Postulated carbon tetrachloride mode of action: A review. $J$. Environ. Sci. Health $C$ Environ. Carcinog. Ecotoxicol. Rev., 25(3): 185-209.

\section{Mansour ZM (2017):}

Hepatoprotective activity and antioxidant effects of avocado (Persea americana) fruits on rat's 
hepatotoxicity induced by carbon tetrachloride". M.Sc. Thesis in Nutrition and Food Science, Faculty of Home Economics, Minoufiya University, Egypt.

Meharam E and SayedAhmed S (2019):

Potential roles of some plant parts on oxidant/antioxidant status and hyperglycemia in diabetic rat. JEDU, 6(29): 741- 775 .

\section{Mehram EB; Aboraya AO and} Elhassaneen YA (2021):

Potential Effects of Food Processing Byproducts on Neurological and Immunological Disorders of Obese Rats. Alexandria Science Exchange Journal, 42, (2): 509-522.

Meyer SA and Kulkarni AP (2001):

Hepatotoxicity. In: Introduction to

Biochemical Toxicology, Hodgson, E. and R.C. Smart (Eds.). Third Edn,
John Wiley and Sons, New York, pp: 487-489.

\section{Misko T; Schilling R; Salvemini D; Moore $W$ and Currie $M$ (1993):}

A Fluorometric assay for the measurement of nitrite in biological samples. Analytical Biochemistry. 214: 11-16.

\section{Morresion $G$ and Hark $L$ (1999): \\ Medical Nutrition and Disease. Second Edition. Black Well Science, Inc.}

\section{Nilanjana M (2013):}

Cardiovascular Diseases:

Nutritional and

Therapeutic Interventions.

CRC Press, Taylor and

Francis Group, London.

\section{NRC, National Research} Council (1996):

Guide for the Care and Use of Laboratory Animals Washington: National Academy Press. New York. 
Pagana KD and Pagana TJ (1997):

Mosby's diagnostic and laboratory test references. 3 rd ed., Mosby-year Book, Inc., New York.

Rahman T; Hosen I; Islam MT and Shekhar HU (2012) :

Oxidative stress and human health. Advances in Bioscience and Biotechnology, 3, 997-1019.

Reeves P; Rossow $K$ and Lindlauf J (1993):

Development and testing of the AIN-93 purified diets for rodents: results on growth, kidney calcification and bone mineralization in rats and mice. J. Nutr., 123(11):1923-1931.

Salman MS (2016):

Immunomodulatory and mineral absorption improvement of some red mushroom. M.Sc. Thesis in Nutrition and Food Science, Faculty of Home Economics, Minoufiya University, Egypt.
Sayed Ahmed S (2016):

Nutritional and technological studies on the effect of phytochemicals on obesity injuries and their related diseases by using experimental animals. Ph.D. Thesis in Home Economics (Nutrition and Food Science), Faculty of Specific Education, Port Said University, Egypt.

\section{Snedecor GW and Cochran WG (1967):}

Statistical Methods" $6^{\text {th }}$ Ed. Iowa State University press. Ames. Lowa. USA.

\section{Susilo RJK; Winarni D; Husen SA; Hayaza S; Punnapayak H; Wahyuningsih SPA and Darmanto W (2019):}

Hepatoprotective effect of crude polysaccharides extracted from Ganoderma lucidum against carbon tetrachloride-induced liver injury in mice, Veterinary World, 12 (12): 19871991. 
Tahoon SR (2019):

Hepatoprotective effect of Apricot and Plum kernel on carbon tetrachloride induced hepatic rats ". M.Sc. Thesis in Nutrition and Food Science, Faculty of Home Economics, Minoufiya University, Egypt.

Tavakkol J; Ghomian N; Shameli A; Shakeri MT; Fahmidehkar M A; Mahajer E; Khoshnavaz $R$ and Emadzadeh M (2005):

Determination of Interleukin-6 and Tumor Necrosis Factor-alpha concentrations in IranianKhorasanian patients with preeclampsia. $B M C$

Pregnancy and Childbirth, 5:2-5.

\section{Tietz NW (1976):}

Fundamental of Clinical Chemistry. Philadelphia, W.B. Saunders, P. 243.

Tomasi S; Lohezic-Le DF; Sauleau P; Bezivin C; and Boustie J (2004):
Cytotoxic activity of methanol extracts from Basidiomycete mushrooms on murine cancer cell lines. Pharmazie.; 59:290-293.

Valko M; Izakovic M; Mazur M; Rhodes CJ and Joshua T (2004):

Role of oxygen radicals in DNA damage and cancer incidence. Mol. Cell Biochem. 266, 37-56.

Vanitha A; Murthy KN; Kumar V; Sakthivelu G; Veigas JM; Saibaba $P$ and Ravishankar GA (2007):

Effect of the carotenoidproducing alga, Dunaliella bardawil, on CCl4induced toxicity in rats. Int. J. Toxicol., 26: 159167.

\section{Vassault \\ A; Grafmeyer} D; Graeve J; Cohen R; Beaudonnet $A$ and Bienvenu $J$ (1999):

Quality specifications and allowable standards for validation of methods used in clinical biochemistry. 
Ann Biol Clin (Paris).

57(6): 685-95.

\section{Venturella G; Ferraro V;}

Cirlincione $\mathrm{F}$ and Gargano ML (2021):

Medicinal Mushrooms:

Bioactive Compounds,

Use, and Clinical Trials.

Int. J. Mol. Sci., 22, 634.).

Voet D and Voet J (1990):

Biochemistry, 1st Ed, JOHN WILEY \& SONS INC., NJ, USA.

Wachtel-Galor S; Yuen J; Buswell JA and Benzie IF (2011):

Ganoderma lucidum (Lingzhi or Reishi): A Medicinal Mushroom. In: Benzie, I.F., WachtelGalor, S., editors. Herbal Medicine: Biomolecular and Clinical Aspects. $2^{\text {nd }} e d$. Boca Raton (FL): $C R C$ Press/Taylor \& Francis; Chapter 9. PMID: 22593926.

Wang FR; Ai H; Chen XM and Lei CL (2007):
Hepatoprotective effect of a protein-enriched fraction from the maggots (Musca domestica) against $\mathrm{CCl} 4$ induced hepatic damage in rats. Biotechnol. Lett, 29(6): 853-858.

WHO, (1999):

World Health Organization. "Environ-mental Health Criteria 208: carbon tetrachloride, Geneva, Switzerland.

\section{Wong F; Tsun-Thai C; Soon-} Leong T and Ann-Li Y (2013):

Evaluation of Bioactivities and Phenolic Content of Selected Edible Mushrooms in Malaysia. Tropical Journal of Pharmaceutical Research, 12 (6): 1011-1016.

Wu Y and Wang DA (2009):

New class of natural glycopeptides with sugar moiety-dependent antioxidant activities derived from Ganoderma lucidum fruiting bodies. $J$ Proteome Res. 8(2), 436442. 
Wu G; Fang YZ; Yang S;

Lupton JR; and Turner ND (2004):

Glutathione metabolism and its implications for health. The Journal of utrition, 134(3), 489-492.

Yu G; Nizhenkovska I.V and Korda MM (2020):

Biological and Bioorganic

Chemistry: in 2 books.

Book 2. Biological

Chemistry; edited by Yu.Gubsky,I.V.Nizhenkov ska. Kyiv: AUS Medicine

Publishing, 2020.-544 p.

\section{Zhong JJ and Xiao J H (2009):}

Secondary metabolites from higher fungi: Discovery, bioactivity and bio-production. Adv Biochem Eng Biotechnol; 113:79-150. 
Table 1. Effect of GLP consumption on BWG, FI and FER of hepatotoxic rats induced by $\mathrm{CCl}_{4}$.

\begin{tabular}{|c|c|c|c|c|c|c|c|}
\hline \multirow[t]{2}{*}{ Value } & \multirow{2}{*}{$\begin{array}{c}\text { Control } \\
(-) \\
\text { Std diet }\end{array}$} & \multirow{2}{*}{$\begin{array}{c}\text { Control } \\
(+) \\
\mathrm{CCl}_{4}\end{array}$} & \multicolumn{5}{|c|}{$\begin{array}{c}\text { Ganoderma lucidum powder } \\
\text { (GLP, w/w) }\end{array}$} \\
\hline & & & 1 & 2 & 3 & 4 & 5 \\
\hline \multicolumn{8}{|c|}{ BWG (\%) } \\
\hline Range & $\begin{array}{l}0.81- \\
0.94\end{array}$ & $\begin{array}{l}0.41- \\
0.47\end{array}$ & $\begin{array}{l}0.50- \\
0.53\end{array}$ & $\begin{array}{l}0.59- \\
0.67\end{array}$ & $\begin{array}{l}0.60- \\
0.79\end{array}$ & $\begin{array}{l}0.65- \\
0.87\end{array}$ & $\begin{array}{l}0.78- \\
0.81\end{array}$ \\
\hline Mean & $0.89^{\mathrm{a}}$ & $0.43^{\mathrm{e}}$ & $0.51^{\mathrm{d}}$ & $0.62^{\mathrm{c}}$ & $0.73^{\mathrm{ab}}$ & $0.78^{a b}$ & $0.79^{a}$ \\
\hline SD & 0.06 & 0.05 & 0.02 & 0.04 & 0.10 & 0.05 & 0.03 \\
\hline $\begin{array}{l}\% \text { of } \\
\text { change }\end{array}$ & 0.00 & -51.69 & -42.70 & -30.34 & -17.98 & -12.36 & -11.24 \\
\hline \multicolumn{8}{|c|}{ FI (g/day/rat) } \\
\hline Range & $\begin{array}{l}12.01- \\
13.13\end{array}$ & $\begin{array}{l}7.54- \\
8.08\end{array}$ & $\begin{array}{l}9.02- \\
9.94\end{array}$ & $\begin{array}{l}10.15- \\
11.41\end{array}$ & $\begin{array}{l}10.65- \\
11.88\end{array}$ & $\begin{array}{l}11.59- \\
12.38\end{array}$ & $\begin{array}{l}11.74- \\
12.90\end{array}$ \\
\hline Mean & $12.59^{a}$ & $8.12^{c}$ & $9.20^{b}$ & $10.89^{a b}$ & $11.50^{\mathrm{a}}$ & $12.10^{\mathrm{a}}$ & $12.20^{\mathrm{a}}$ \\
\hline SD & 0.78 & 0.45 & 0.64 & 0.71 & 0.72 & 0.53 & 0.62 \\
\hline $\begin{array}{l}\% \text { of } \\
\text { change }\end{array}$ & 0.00 & -35.50 & -26.93 & -13.50 & -8.66 & -3.89 & -3.10 \\
\hline \multicolumn{8}{|c|}{ FER } \\
\hline Range & $\begin{array}{l}0.068- \\
0.072\end{array}$ & $\begin{array}{l}0.049- \\
0.054\end{array}$ & $\begin{array}{l}0.051- \\
0.063\end{array}$ & $\begin{array}{l}0.051- \\
0.058\end{array}$ & $\begin{array}{l}0.060- \\
0.069\end{array}$ & $\begin{array}{l}0.059- \\
0.070\end{array}$ & $\begin{array}{l}0.062- \\
0.067\end{array}$ \\
\hline Mean & $0.071^{a}$ & $0.052^{\mathrm{c}}$ & $0.055^{\mathrm{c}}$ & $0.056^{\mathrm{c}}$ & $0.063^{b}$ & $0.064^{b}$ & $0.065^{b}$ \\
\hline SD & 0.002 & 0.009 & 0.005 & 0.004 & 0.004 & 0.006 & 0.002 \\
\hline $\begin{array}{l}\% \text { of } \\
\text { change }\end{array}$ & 0.00 & -26.76 & -22.54 & -21.13 & -11.27 & -9.86 & -8.45 \\
\hline
\end{tabular}

* Means in the same row with different letters are significantly different at $p \leq 0.05$ 
Table 2. Effect of G. lucidum consumption on liver functions of hepatotoxic rats induced by $\mathrm{CCl}_{4}$.

\begin{tabular}{|c|c|c|c|c|c|c|c|}
\hline \multirow[t]{2}{*}{ Value } & \multirow{2}{*}{$\begin{array}{c}\text { Control } \\
(-) \\
\text { Std diet }\end{array}$} & \multirow{2}{*}{$\begin{array}{c}\text { Control } \\
\text { (+) } \\
\mathrm{CCl}_{4}\end{array}$} & \multicolumn{5}{|c|}{$\begin{array}{c}\text { Ganoderma lucidum powder } \\
\text { (GLP, w/w) }\end{array}$} \\
\hline & & & 1 & 2 & 3 & 4 & 5 \\
\hline \multicolumn{8}{|c|}{ Serum Aspartate aminotransferase (AST) activity (U/L) } \\
\hline Range & $\begin{array}{l}46.11 \\
-56.76\end{array}$ & $\begin{array}{l}85.55 \\
-97.45\end{array}$ & $\begin{array}{l}77.45 \\
-88.42\end{array}$ & $\begin{array}{l}70.65 \\
-79.62\end{array}$ & $\begin{array}{l}60.66 \\
-71.33\end{array}$ & $\begin{array}{l}54.72 \\
-68.44\end{array}$ & $\begin{array}{l}53.78 \\
-63.09\end{array}$ \\
\hline Mean & $52.87^{\mathrm{e}}$ & $92.15^{\mathrm{a}}$ & $81.42^{\mathrm{b}}$ & $76.76^{\mathrm{c}}$ & $65.92^{\mathrm{d}}$ & $60.51^{\mathrm{d}}$ & $58.65^{\mathrm{d}}$ \\
\hline SD & 5.66 & 8.99 & 6.44 & 5.76 & 7.12 & 8.63 & 7.03 \\
\hline $\begin{array}{l}\% \text { of } \\
\text { change }\end{array}$ & 0.00 & 74.29 & 54.00 & 45.18 & 24.68 & 14.45 & 10.93 \\
\hline \multicolumn{8}{|c|}{ Serum alanine aminotransferase (ALT) activity (U/L) } \\
\hline Range & $\begin{array}{l}26.77 \\
-35.76\end{array}$ & $\begin{array}{l}66.76 \\
-73.90\end{array}$ & $\begin{array}{l}55.09 \\
-66.20\end{array}$ & $\begin{array}{l}49.02 \\
-56.12\end{array}$ & $\begin{array}{l}41.03 \\
-52.55\end{array}$ & $\begin{array}{l}34.44 \\
-40.81\end{array}$ & $\begin{array}{l}34.78 \\
-43.22\end{array}$ \\
\hline Mean & $31.12^{\mathrm{e}}$ & $69.57^{\mathrm{a}}$ & $59.15^{b}$ & $52.65^{c}$ & $46.82^{\mathrm{cd}}$ & $37.79^{\mathrm{d}}$ & $36.21^{\mathrm{d}}$ \\
\hline SD & 4.34 & 6.92 & 5.54 & 4.91 & 6.12 & 4.90 & 5.21 \\
\hline $\begin{array}{l}\% \text { of } \\
\text { change }\end{array}$ & 0.00 & 123.55 & 90.06 & 69.19 & 50.44 & 21.43 & 16.36 \\
\hline \multicolumn{8}{|c|}{ Serum alkaline phosphatase (ALP,U/L) } \\
\hline Range & \begin{tabular}{|l}
98.99 \\
-117.03
\end{tabular} & $\begin{array}{l}271.9 \\
-321.17\end{array}$ & $\begin{array}{l}255.67- \\
281.72\end{array}$ & $\begin{array}{l}220.98- \\
266.20\end{array}$ & $\begin{array}{l}287.11- \\
2016.54\end{array}$ & $\begin{array}{l}137.78- \\
166.54\end{array}$ & $\begin{array}{l}130.86 \\
-151.45\end{array}$ \\
\hline Mean & $106.43^{\mathrm{g}}$ & $294.34^{\mathrm{a}}$ & $270.12^{b}$ & $243.98^{\mathrm{c}}$ & $202.29^{\mathrm{d}}$ & $152.54^{\mathrm{e}}$ & $139.09^{\mathrm{f}}$ \\
\hline SD & 10.32 & 27.14 & 13.66 & 25.85 & 14.12 & 20.89 & 11.23 \\
\hline $\begin{array}{l}\% \text { of } \\
\text { change }\end{array}$ & 0.00 & 176.56 & 153.80 & 129.24 & 90.07 & 43.32 & 30.69 \\
\hline
\end{tabular}

${ }^{*}$ Means in the same row with different letters are significantly different at $\mathrm{p} \leq 0.0$ 
Potential Protective Effects of Ganoderma lucidum Powder against Carbon Tetrachloride Induced Liver Disorders in rats: Biological, Biochemical and Immunological Studies

Sara A. Sayed Ahmed; Nahed S. Abd Elalal and Yousif A. Elhassaneen

Table 3: Effect of G. lucidum consumption on immunological markers of hepatotoxic rats induced by $\mathrm{CCl}_{4}$.

\begin{tabular}{|c|c|c|c|c|c|c|c|}
\hline \multirow[t]{2}{*}{ Value } & \multirow{2}{*}{$\begin{array}{l}\text { Control } \\
\text { (-) St. diet }\end{array}$} & \multirow{2}{*}{$\begin{array}{c}\text { Control (+) } \\
\mathrm{CCl}_{4}\end{array}$} & \multicolumn{5}{|c|}{ Ganoderma lucidum powder (GLP, w/v } \\
\hline & & & 1 & 2 & 3 & 4 & 5 \\
\hline \multicolumn{8}{|c|}{ Albumin concentration, $(\mathrm{Alb}, \mathrm{g} / \mathrm{dl})$} \\
\hline Range & \begin{tabular}{|l|}
3.90 \\
-4.36 \\
\end{tabular} & $\begin{array}{l}1.79 \\
-3.06\end{array}$ & $\begin{array}{l}2.79 \\
-3.05\end{array}$ & $\begin{array}{l}2.90 \\
-3.30\end{array}$ & $\begin{array}{l}3.29 \\
-3.66\end{array}$ & $\begin{array}{l}3.48 \\
-3.82\end{array}$ & \begin{tabular}{|l|}
3.56 \\
-3.97
\end{tabular} \\
\hline Mean & $4.11^{\mathrm{a}}$ & $2.90^{\mathrm{e}}$ & $2.97^{\mathrm{d}}$ & $3.13^{\mathrm{c}}$ & $3.49^{\mathrm{bc}}$ & $3.69^{\mathrm{b}}$ & $3.82^{\mathrm{b}}$ \\
\hline SD & 0.23 & 0.12 & 0.10 & 0.21 & 0.22 & 0.19 & 0.26 \\
\hline$\%$ of change & 0.00 & -29.44 & -27.74 & -23.84 & -15.09 & -10.22 & -7.06 \\
\hline \multicolumn{8}{|c|}{ Tumor necrosis factor- $\alpha$ level, (TNF- $\alpha, \mathrm{ng} / \mathrm{L})$} \\
\hline Range & \begin{tabular}{|l|}
1.26 \\
-1.50
\end{tabular} & $\begin{array}{l}2.41 \\
-2.77\end{array}$ & $\begin{array}{l}2.12 \\
-2.37\end{array}$ & $\begin{array}{l}1.85 \\
-1.97\end{array}$ & $\begin{array}{c}1.64 \\
-1.89\end{array}$ & $\begin{array}{l}1.59 \\
-1.71\end{array}$ & $\begin{array}{l}1.46 \\
-1.76\end{array}$ \\
\hline Mean & $1.34^{\mathrm{d}}$ & $2.59^{\mathrm{a}}$ & $2.22^{\mathrm{b}}$ & $1.92^{\mathrm{b}}$ & $1.75^{\mathrm{bc}}$ & $1.63^{\mathrm{bc}}$ & $1.61^{\mathrm{bc}}$ \\
\hline SD & 0.11 & 0.20 & 0.13 & 0.08 & 0.13 & 0.06 & 0.18 \\
\hline \% of change & 0.00 & 93.28 & 65.67 & 43.28 & 30.60 & 21.64 & 20.15 \\
\hline
\end{tabular}

${ }^{*}$ Means in the same row with different letters are significantly different at $p \leq 0.05$

Table 4. Effect of G. lucidum consumption on glutathione fractions of hepatotoxic rats induced by $\mathrm{CCl}_{4}$.

\begin{tabular}{|c|c|c|c|c|c|c|c|}
\hline \multirow[t]{2}{*}{ Value } & \multirow{2}{*}{$\begin{array}{r}\text { Control (-) } \\
\text { St diet }\end{array}$} & \multirow{2}{*}{$\begin{array}{c}\text { Control (+) } \\
\mathrm{CCl}_{4}\end{array}$} & \multicolumn{5}{|c|}{ Ganoderma lucidum powder (GLP, w/w) } \\
\hline & & & 1 & 2 & 3 & 4 & 5 \\
\hline \multicolumn{8}{|c|}{ Reduced glutathione concentration, $(\mathrm{GSH}, \mu \mathrm{mol} / \mathrm{L})$} \\
\hline Range & $\begin{array}{l}7.59 \\
-8.55\end{array}$ & $\begin{array}{l}5.02 \\
-5.87\end{array}$ & $\begin{array}{l}5.90 \\
-7.33\end{array}$ & $\begin{array}{l}5.79 \\
-7.91\end{array}$ & $\begin{array}{l}7.11 \\
-7.74\end{array}$ & $\begin{array}{l}7.20 \\
-8.29\end{array}$ & $\begin{array}{l}6.03 \\
-8.06\end{array}$ \\
\hline Mean & $8.61^{\mathrm{a}}$ & $5.91^{\mathrm{d}}$ & $6.52^{c}$ & $6.88^{c}$ & $7.41^{\mathrm{b}}$ & $7.84^{\mathrm{b}}$ & $7.99^{\mathrm{b}}$ \\
\hline SD & 1.10 & 0.98 & 0.87 & 1.14 & 0.39 & 0.59 & 1.14 \\
\hline$\%$ of change & 0.00 & -31.36 & -24.27 & -20.09 & -13.94 & -8.94 & -7.20 \\
\hline \multicolumn{8}{|c|}{ Oxidized glutathione concentration (GSSG, $\mu \mathrm{mol} / \mathrm{L}$ ) } \\
\hline Range & $\begin{array}{l}0.61 \\
1-0.708\end{array}$ & $\begin{array}{l}0.483 \\
-0.662\end{array}$ & $\begin{array}{l}0.541 \\
-0.619\end{array}$ & $\begin{array}{l}0.551 \\
-0.622\end{array}$ & $\begin{array}{l}0.545 \\
-0.660\end{array}$ & $\begin{array}{l}0.510 \\
-0.718\end{array}$ & $\begin{array}{l}0.580 \\
-0.649\end{array}$ \\
\hline Mean & $0.671^{\mathrm{a}}$ & $0.572^{\mathrm{cd}}$ & $0.583^{c}$ & $0.587^{c}$ & $0.608^{b}$ & $0.610^{\mathrm{b}}$ & $0.620^{b}$ \\
\hline SD & 0.045 & 0.102 & 0.054 & 0.042 & 0.059 & 0.112 & 0.038 \\
\hline$\%$ of change & 0.00 & -14.75 & -13.11 & -12.52 & -9.39 & -9.09 & -7.60 \\
\hline \multicolumn{8}{|c|}{ GSH/GSSG ratio (\%) } \\
\hline Value & $12.832^{\mathrm{a}}$ & $10.332^{c}$ & $11.184^{b}$ & $11.721^{\mathrm{b}}$ & $12.188^{\mathrm{a}}$ & $12.852^{\mathrm{a}}$ & $12.887^{\mathrm{a}}$ \\
\hline$\%$ of change & 0.00 & -19.48 & -12.84 & -8.66 & -5.019 & 0.156 & 0.429 \\
\hline
\end{tabular}

${ }^{*}$ Means in the same row with different letters are significantly different at $p \leq 0$. 
Table 5. Effect of $G$. lucidum consumption on oxidative stress of hepatotoxic rats induced by $\mathrm{CCl}_{4}$.

\begin{tabular}{|c|c|c|c|c|c|c|c|}
\hline \multirow[t]{2}{*}{ Value } & \multirow{2}{*}{$\begin{array}{c}\text { Control } \\
\quad(-) \\
\text { Std diet }\end{array}$} & \multirow{2}{*}{$\begin{array}{c}\text { Control } \\
(+) \\
\mathrm{CCl}_{4}\end{array}$} & \multicolumn{5}{|c|}{$\begin{array}{l}\text { Ganoderma lucidum powder } \\
\text { (GLP, w/w) }\end{array}$} \\
\hline & & & 1 & 2 & 3 & 4 & 5 \\
\hline \multicolumn{8}{|c|}{ Malondialdehyde concentration (MDA, $\mathrm{nmol} / \mathrm{mL}$ ) } \\
\hline Range & $\begin{array}{l}0.161 \\
-0.194\end{array}$ & $\begin{array}{l}.0 .329 \\
-0.412\end{array}$ & $\begin{array}{l}0.313 \\
0.352\end{array}$ & $\begin{array}{l}0.280 \\
-0,314\end{array}$ & $\begin{array}{l}0.275 \\
-0.296\end{array}$ & $\begin{array}{l}0.218 \\
-0.246\end{array}$ & $\begin{array}{l}0.208- \\
0.263\end{array}$ \\
\hline Mean & $0.179^{\mathrm{e}}$ & $0.391^{\mathrm{a}}$ & 0.331 & \begin{tabular}{l|l}
$\mathrm{a}$ & $0.299^{\mathrm{ab}}$
\end{tabular} & $\begin{array}{l}\mathrm{ab} \\
0.284^{\mathrm{b}}\end{array}$ & \begin{tabular}{l|l}
$\mathrm{b}$ & $0.229^{\mathrm{c}}$
\end{tabular} & \begin{tabular}{l|l}
$\mathrm{c}$ & $0.223^{\mathrm{c}}$
\end{tabular} \\
\hline SD & 0.033 & 0.031 & 0.029 & 0.044 & 0.039 & 0.059 & 0.045 \\
\hline $\begin{array}{l}\% \text { of } \\
\text { change }\end{array}$ & 0.00 & 118.44 & 84.92 & 67.04 & 58.66 & 27.93 & 24.58 \\
\hline \multicolumn{8}{|c|}{ Nitrite $\left(\mathrm{NO}_{2}, \mathbf{n m o l} / \mathrm{L}\right)$} \\
\hline Range & \begin{tabular}{|l|}
2.25 \\
-2.54 \\
\end{tabular} & \begin{tabular}{|l|}
4.51 \\
-5.24 \\
\end{tabular} & $\begin{array}{l}3.92 \\
-5.13\end{array}$ & $\begin{array}{l}3.23 \\
-4.98 \\
\end{array}$ & $\begin{array}{l}2.99 \\
-4.08\end{array}$ & $\begin{array}{l}3.10 \\
-3.88 \\
\end{array}$ & $\begin{array}{l}2.32 \\
-3.32 \\
\end{array}$ \\
\hline Mean & $2.39^{\mathrm{e}}$ & $4.87^{a}$ & $4.65^{a}$ & $4.05^{b}$ & $3.66^{c}$ & $3.54^{\mathrm{c}}$ & $2.85^{\mathrm{d}}$ \\
\hline SD & 0.17 & 0.43 & 0.87 & 1.01 & 0.49 & 0.48 & 0.56 \\
\hline $\begin{array}{l}\text { \% of } \\
\text { change }\end{array}$ & 0.00 & 103.77 & 94.56 & 69.46 & 53.14 & 48.12 & 19.25 \\
\hline
\end{tabular}

* Means in the same row with different letters are significantly different at $p \leq 0.05$ 


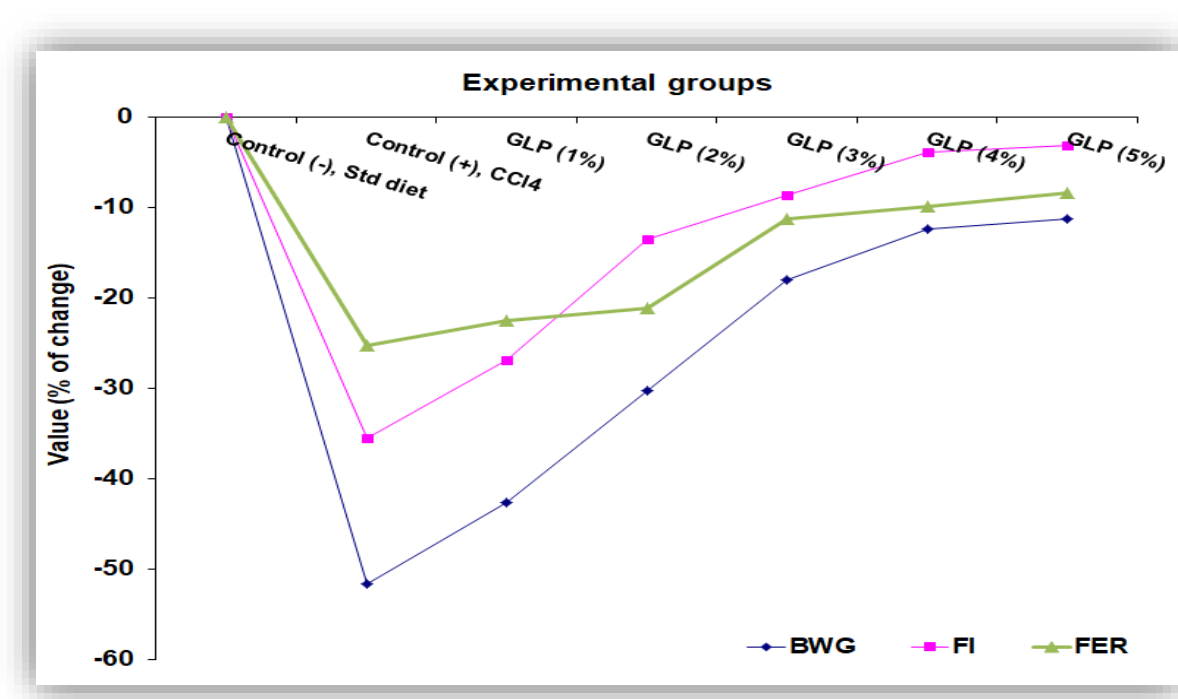

Figure 1. Effect of GLP consumption on BWG, FI and FER of hepatic disorder rats induced by $\mathrm{CCl}_{4}$

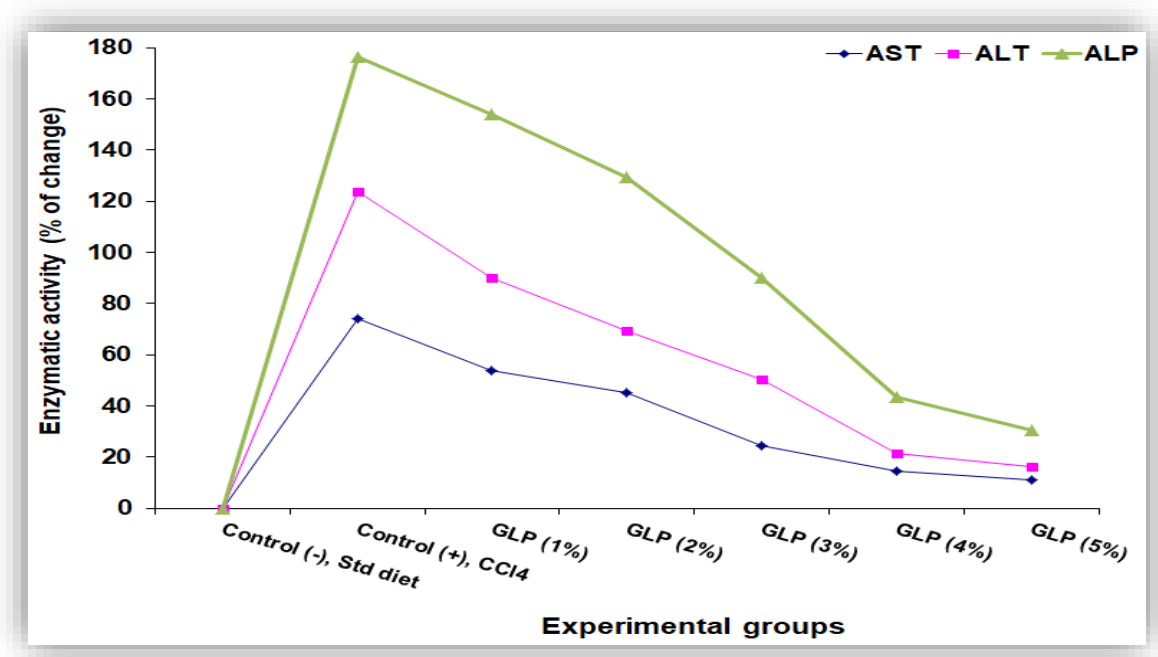

Figure 2. Effect of G. lucidum consumption on liver functions of hepatotoxic rats induced by $\mathrm{CCl}_{4}$ 


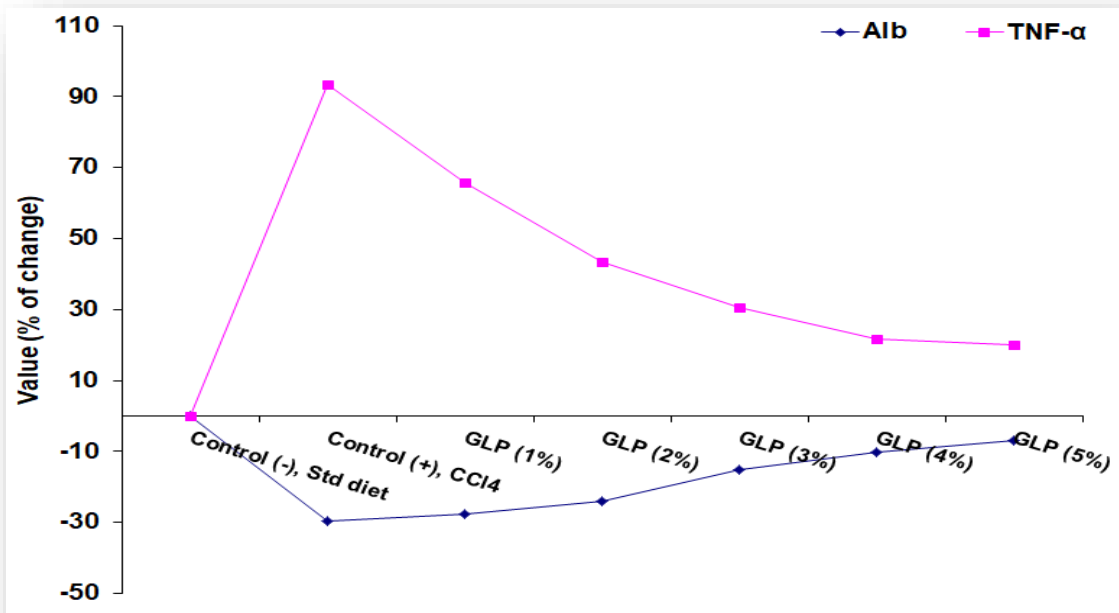

Experimental groups

Figure 3. Effect of G. lucidum consumption on immunological markers of hepatotoxic rats induced by $\mathrm{CCl}_{4}$

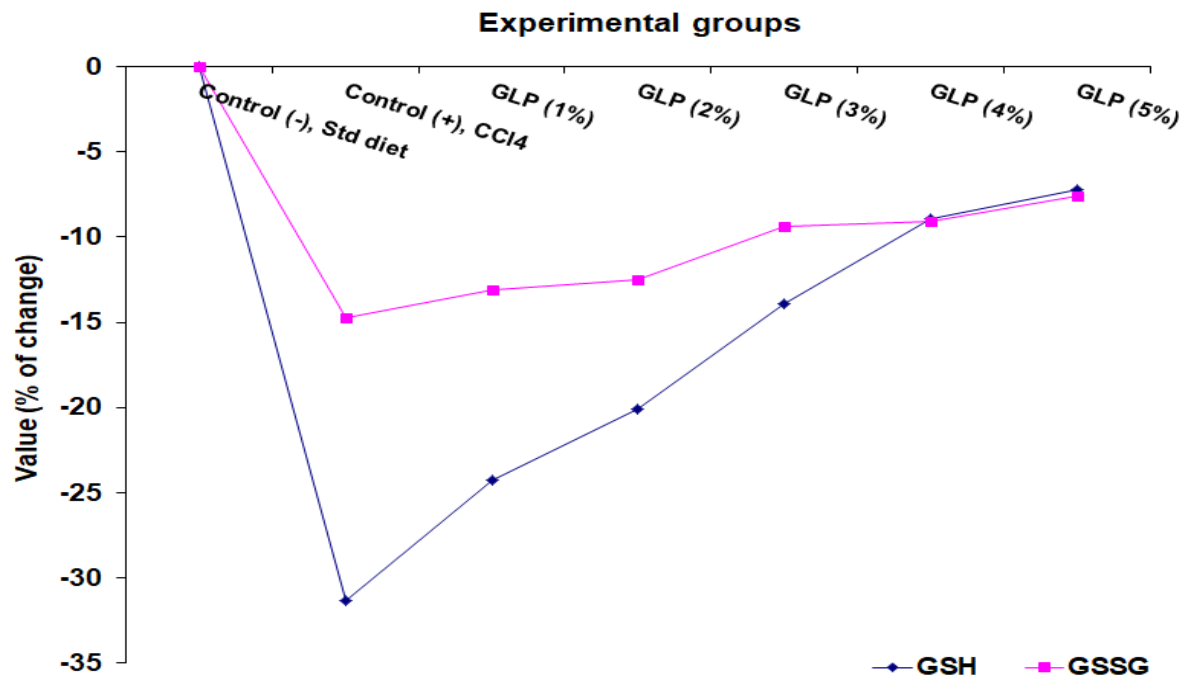

Figure 4. Effect of G. lucidum consumption on glutathione fractions of hepatotoxic rats induced by $\mathrm{CCl}_{4}$ 


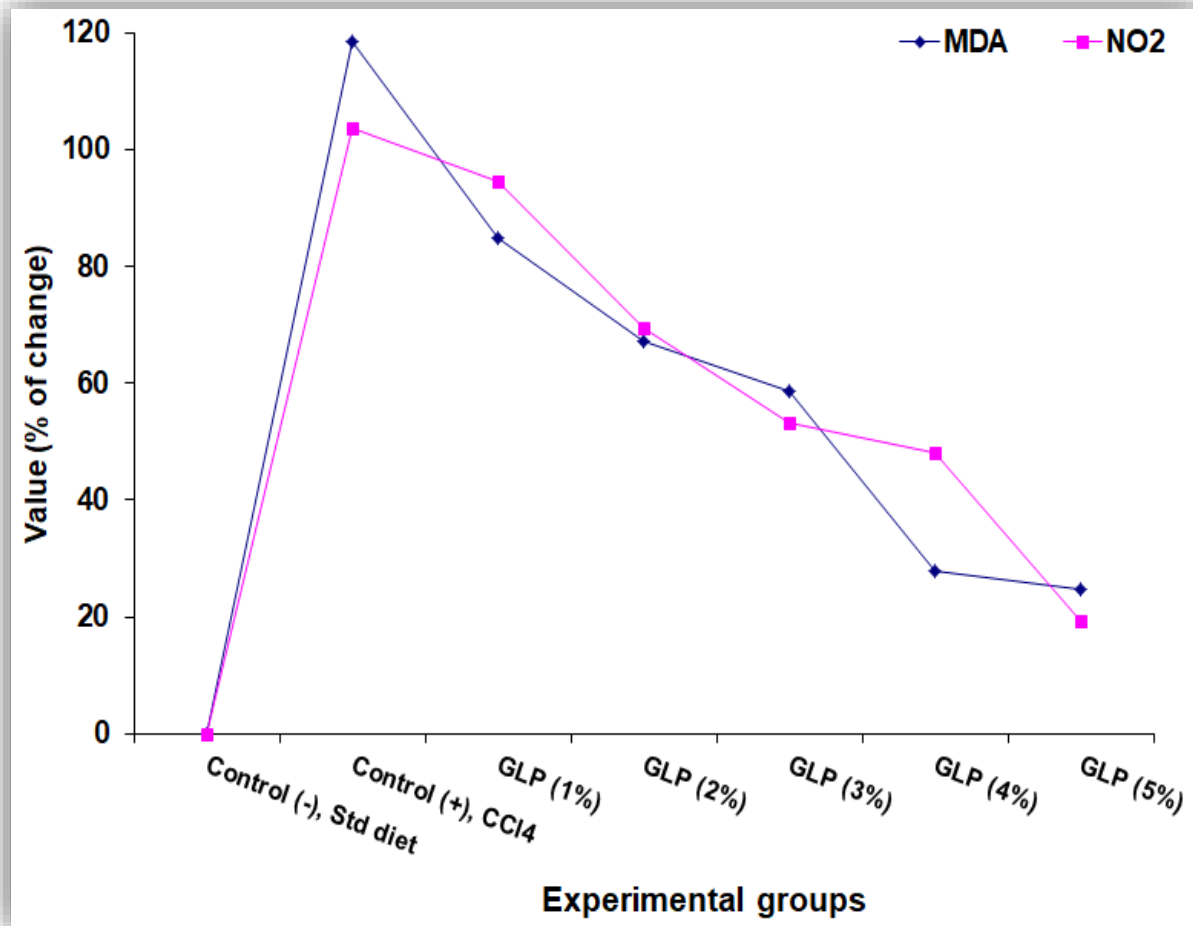

Figure 5. Effect of G. lucidum consumption on oxidative stress of hepatotoxic rats induced by $\mathrm{CCl}_{4}$ 


\section{التأثيرات الوقائية المحتملة لمسحوق الجانوديرما ضد اضطرابات الكبا}

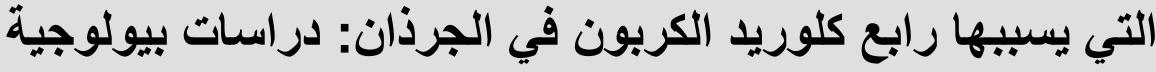
وبيوكيميائية ومناعية في الجرذان

\section{سارة سيد أحمد' ، ناهد شحاتة عبد العال ‘، يوسف عبد العزيز الحساتينج}

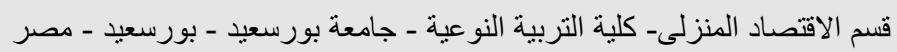

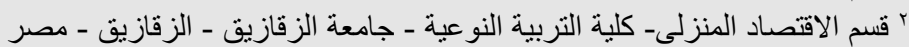

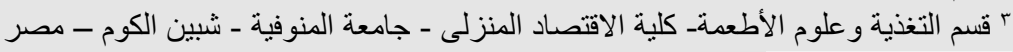
الملخص العربي النغي

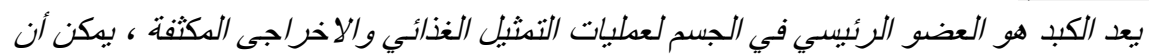

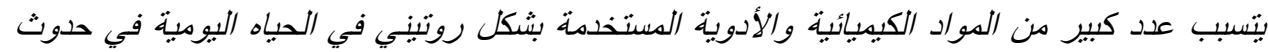

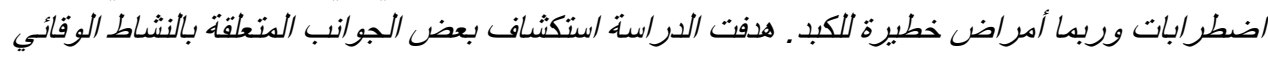

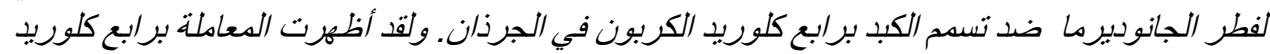

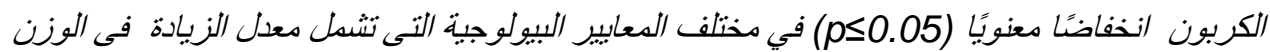

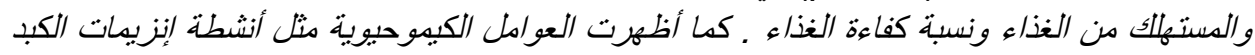

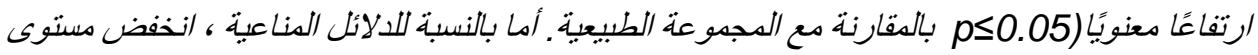

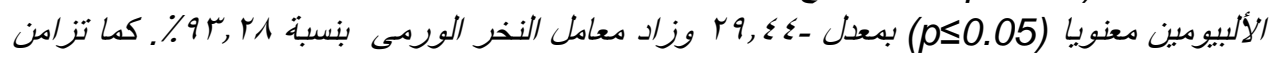

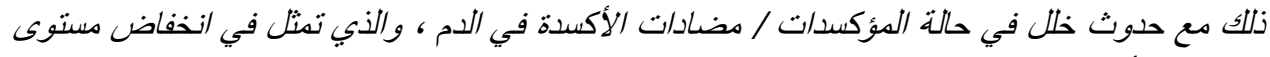

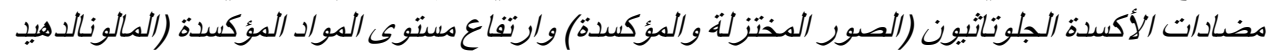

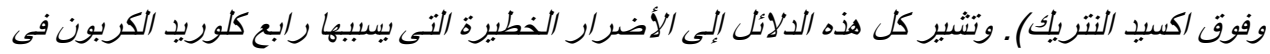

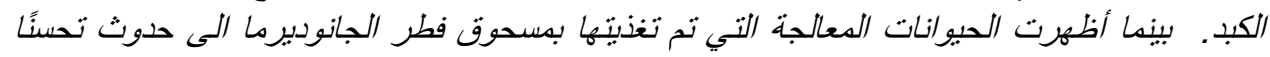

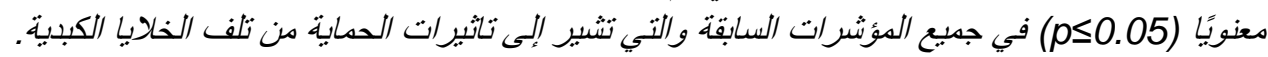

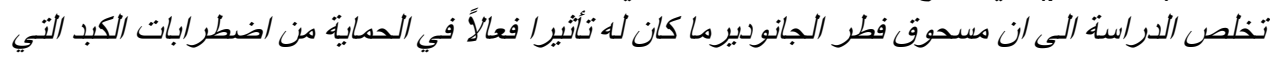

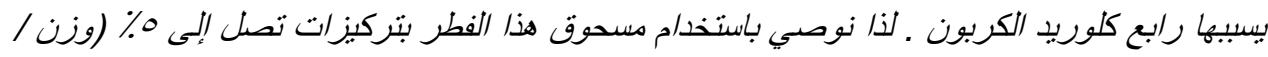

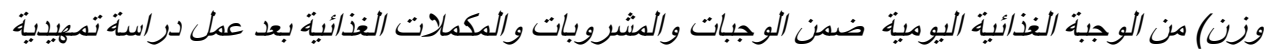
على اناس متطو عنين. الكلمات المفتاحية: مسحوق الجوانودرما ، الدلائل البيولوجية والمناعية. 